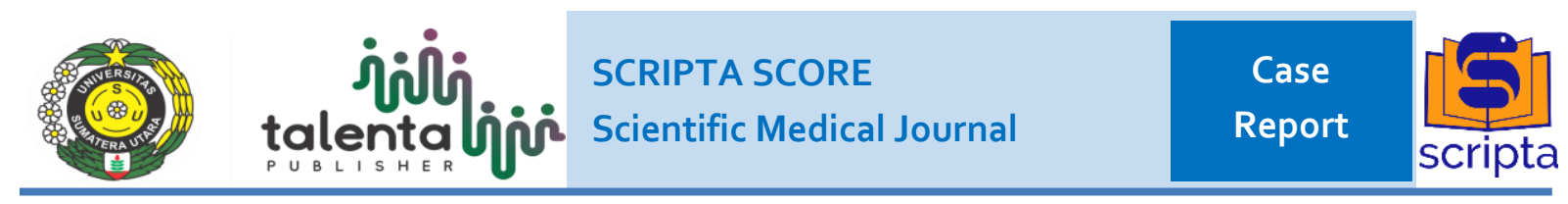

\title{
Clinical Features of Apert Syndrome in Infancy: A rare case in Indonesia
}

\author{
Muhammad Pradhika Mapindra, Muhammad Pradhiki Mahindra \\ Department of Anatomy, Faculty of Medicine, Hasanuddin University, Makassar
}

\begin{abstract}
Background: Apert syndrome is characterized by several malformations of cranial-facial and syndactyly. The incidence of Apert syndrome was reported at approximately 1 per 65,000 live births, globally. Fibroblast Growth Factor 2 (FGFR2) is believed to hold a key role in the syndrome. Objectives: This case report is aiming to describe the information on a rare incidence of craniosynostosis syndromes on Indonesian infants. Case Illustration: One month old female baby was admitted to the hospital due to the breastfeeding difficulty caused by cleft palate. The patient was known to experience defects of face-head features and syndactyly since birth. This patient was observed and controlled to undergo nasogastric feeding until meet the appropriate age for surgical therapy. Discussion: Mutation of Ser252Trp and Pro253Arg was found in the patient. Based on this finding, this case report may strengthen the statement about the correlation between Ser252Trp and cleft palate whereas Pro253Arg is linked with syndactyly in individuals with the syndrome. Conclusion:. This case may give beneficial information for clinicians when they receive a patient with the same clinical features. However, further investigation to know this syndrome still needs to be developed.
\end{abstract}

Keywords: Apert Syndrome, FGFR2, palate cleft, Pro253Arg, Ser252Trp

\section{ABSTRAK}

Latar Belakang: Pasien dengan sindroma Apert memiliki fitur karakteristik berupa malformasi kepala dan wajah disertai syndactyly. Insidensi sindroma ini berkisar 1 per 65.000 kelahiran hidup secara global. Etiologi kelainan ini dikatikan dengna mutase pada Fibroblast Growth Factor 2 (FGFR2). Tujuan: Laporan kasus ini bertujuan untuk mendeskripsikan kejadian langka dari sindroma craniosynostosis pada bayi Indonesia. Ilustrasi Kasus: Bayi perempuan usia 1 bulan dibawa ke rumah sakit dengan masalah menyusui akibat palatoschizis. Pasien memiliki riwayat defek wajah dan kepala disertai syndactyly sejak lahir. Pasien ini kemudian diobservasi melalui diet per nasogastric tube sampai siap dilakukan terapi pembedahan. Pembahasan: Mutasi pada Ser252Trp dan Pro253Arg ditemukan pada pasien ini. Sehingga, laporan kasus ini mungkin memperkuat temuan mengenai korelasi Ser252Trp dan palatoschizis sedangkan Pro253Arg dikaitkan dengan syndactyly. Kesimpulan: Kasus ini mungkin dapat memberikan informasi tambahan sebagai referensi untuk klinisi ketika menerima pasien dengan gejala klinis serupa. Namun, studi terkait perlu diperdalam untuk mengetahui lebih jauh mengenai sindroma serupa.

Kata Kunci: FGFR2, palatoschizis, Pro253Arg, Ser252Trp, sindroma Apert Received [10 Sep 2020] | Revised [19 Dec 2020] | Accepted [22 Dec 2020]

\section{INTRODUCTION}

Apert syndrome is a birth defect characterized by combined malformations including marked bony fusion due to craniosynostosis, a cone-shaped calvarium, midface hypoplasia, ocular manifestations, and syndactyly of both hands and feet. This syndrome is believed to be related to the mutations in Fibroblast Growth Factor 2 (FGFR2) that will induce the anatomic abnormalities. $^{[1]}$

Apert syndrome was originally described on a patient with an acrocephalosyndactyly feature by a French pediatrician named Charles Apert in 1906. Apert syndrome was reported in $4.5 \%$ cases out of $21 \%$ syndromic cases of all 
craniosynostosis cases. The prevalence of this syndrome is reported to be around 65,000-75,000 livebirths with the highest proportion reported in the Asian population in 1 per 45,000 live births regardless of gender. ${ }^{[2]}$

Due to an uncommon variety of craniosynostosis abnormality reports in Indonesia. Hereby, we report a rare case report in the Indonesian infant of Apert syndrome supported by the FGFR2 mutation.

\section{CASE ILLUSTRATION}

A 1-year old female infant was admitted to the department of Paediatric of Hasanuddin University Hospital due to the chief complaint of body weight loss for the last one month and mild-moderate dehydration caused by breastfeeding incapability. The patient was born via cesarean section with $2,150 \mathrm{~g}$ birth weight to a 29-year old woman $37^{\text {th }}$ weeks old pregnancy with no history of asphyxia and other newborn problems. Also, there was a history of genetic testing that showed the mutations in FGFR2 measured since the age of less than 1 year old. Her parents informed that the diagnosis of Apert syndrome was confirmed by analyses of molecular genetic testing of which indicating heterozygous genes for the mutation of FGFR2, Ser252Trp, and Pro253Arg.

She was the first child of a healthy mother without any history of abortion. There was no history of the same syndromic condition in her family. Also, her parents were not having a consanguinity marriage. However, they acknowledged that their past ancestors permit a consanguineous tradition between cousins. During the facial examination of the infant with marked clinical signs consist of midface hypoplasia, hypertelorism, low set ears, proptosis followed with shallowing of the eye's orbit. Also, from the complete physical examination, the infant suffered syndactyly of fingers in both arms and feet (Figure 1). Coronal suture was found closed and fused to bony structures.

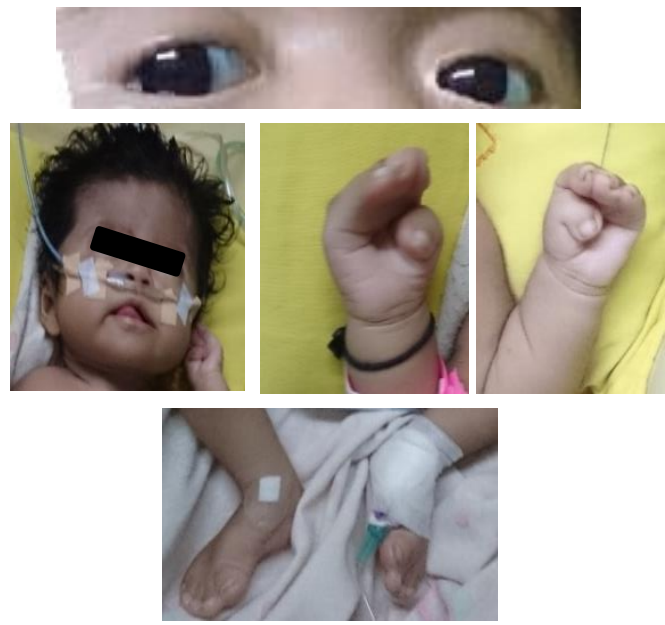

Figure 1. Clinical appearances of facial features and syndactyly fingers suggest to Apert syndrome

The patient was experiencing breastfeeding difficulty because of the palate cleft condition (Figure 2). The first management of this infant was by administering milk via a nasogastric tube route to assure her diet intake.

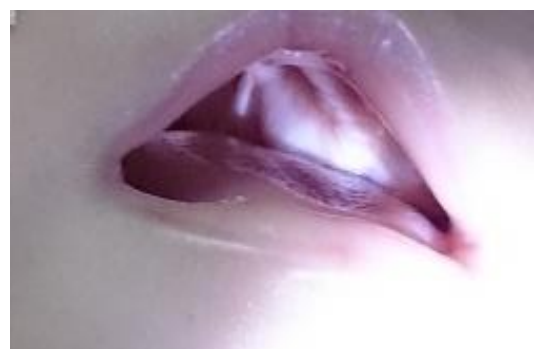

Figure 2. Palate cleft appearance with an appearance of nasogastric tube

Afterward, the infant was discharged after 6 days for fluid therapy to maintain her hydration status and therefore arranged to undergo nasogastric feeding at home. Expectant management was done to observe patients before surgical management would be performed at an appropriate body weight. Once the patient had met the criteria of the rule of $10 \mathrm{~s}$, palatoplasty, the surgical procedure of cleft palate repair may be considered safe for patients. 


\section{DISCUSSION}

From the physical examination, the clinical appearances of the patient that were found namely craniosynostosis syndromes with syndactyly. Hence, the marked clinical findings suggested the diagnosis of Apert syndrome. Such anomaly could be clinically found in the early age of infants with noted characteristics consisting craniosynostosis, midface retrusion, and vertebral fusions. However, the presence of syndactyly that was detected during prenatal diagnosis or afterbirths may accentuate this syndrome from the other akin craniosynostosis anomalies like Crouzon, Pfeiffer, JacksonWeiss, and Beare-Stevenson. ${ }^{[3]}$

In this case, the patient's coronal suture was fused. In Apert syndrome, the coronal suture area is commonly closed prematurely about $<3$ months after delivery leading to a condition of craniofacial complex dysmorphologies. ${ }^{[3,4]}$ However, infants with Apert syndrome might also be born with a fusion of one or more cranial sutures whereas in some other cases, most major cranial sutures would not get fused until the adult age. ${ }^{[3]}$

Several outcomes that maybe happened in this syndrome vary widely. Mental disorder due to abnormalities of brain development and in several severe cases may be followed by abnormalities in the cardio-respiratory system inducing to the worsening condition of the patient until death. ${ }^{[5]}$ Besides, cleft palate is reported as one of the manifestations in Apert syndrome used to distinguish it from Crouzon Syndrome. Palatal anomalies in the early years of infancy cause difficulty to perform suction capabilities that could lead to feeding problems and therefore insufficient volume of required intake. ${ }^{[3]}$ Also, the condition of choanae stricture would induce a respiratory distress syndrome that makes them have to breathe via an open mouth when sucking for breast milk. $^{[3]}$
The history of genetic testing showed that the patient had FGFR2 mutated. Mutation in Fibroblast Growth Factor 2 (FGFR2) is known to promote an abundance of precursor cells that affect the osteogenic pathway. Following this, subperiosteal bone matrix formation and premature ossification of fetal calvaria tend to occur and therefore lead to fused suture and single bony structure which will restrict the perpendicular growth of the head. Besides, the further growth of the brain would be allowed in the remaining unfused sutures. These consecutive events could cause craniofacial dysmorphologies in $\mathrm{AS}^{[6]}$

The patient in this study had a palate cleft which could be seen clearly by inserting the nasogastric tube. A genetic mutation of genes in Ser252Trp and Pro253Arg is believed to affect the condition of cleft palate and syndactyly, respectively. ${ }^{[1,5]}$

In this case, the infant underwent nasogastric tube feeding at home for nutritional support. In a case series on 13 consecutive infants, due to uncoordinated suck-swallow-breathe patterns, they were unable to maintain sucking bursts, and experiencing respiratory pattern changes, lead to a risk of aspiration. ${ }^{[7]}$

Apert syndrome is a clinical entity presenting a spectrum of inherited abnormalities. Thus, management approaches to be taken into consideration can vary, ranging from options of medical care to surgical corrective strategies. In case of upper airway obstruction occurring particularly in the neonatal period, other than oxygen supplementation and topical decongestant, supportive measurements remain to be helpful, including clearing the airway from nasal secretions and treating the upper airway infection. Antimicrobial therapies are also beneficial to treat the accompanying chronic middle ear effusion. Additionally, the use of polysomnography may be also rewarding whenever sleep apnea is reported. ${ }^{[3,6]}$ 
Surgical care which acceptably taken into account consist of 1) Cranial surgery to reduce intracranial pressure, remove synostotic sutures and reshape the calvaria; 2) Reconstruction of nasal anatomy; 3) Midfacial surgery and widening of nasopharyngeal airways, and 4) Mandibular osteotomies. ${ }^{[6]}$ The patient in this case report was planned to underway surgery after met the cut-off of the rule of 10s: aged older than 10 weeks, weight greater than $10 \mathrm{lb}(>4.5 \mathrm{~kg})$, hemoglobin levels at least $10 \mathrm{~g} / \mathrm{dl}$, leukocyte count not more than 10,000 cells/ $\mu \mathrm{l} .{ }^{[8]}$ However, although the patient had an appropriate age for surgery procedure, the body weight was not eligible enough, due to difficulties of maintaining nutritional intake. Preoperation screening turns out to be very essential, to minimize the morbidity risk after the surgery following the capability of patients to safely undergo anesthetic and surgical procedures. ${ }^{[8]}$

Thus, patients with Apert syndrome that can be accompanied by nutritional intake problems, problems related to it must have been detected since the beginning and treated carefully to actualize the patient optimization before the surgery.

\section{CONCLUSION}

In summary, patient in this case was struggling to obtain the nutrition she needed. Due to uncoordinated suckswallow-breathe patterns, she was unable to get a proper diet and therefore lost her bodyweight. As one of the most important criteria to undergo surgery, bodyweight should be more than $10 \mathrm{lb}$ (> $4.5 \mathrm{~kg}$ ). Laryngeal aspiration was reported to be able to induce a failure to thrive condition. Dietetic intervention and enteral supplements can be considered to balance patients' feeding difficulties.

Apert syndrome becomes one of the clinical entities found, quite concerning particularly during infants' period of growth as it may affect infants' inabilities to feed on properly. Adequately treating the infants with medical care and sufficient nutritional intake, in addition to surgical care is therefore desired. Apert syndrome is a very complex abnormality, a multidisciplinary approach is crucial to managing the anomaly. Routine measurements consisting of anthropometry, cardiorespiratory assessment, neuro-developmental status, and feeding evaluation must have been prioritized to optimize the patients' condition.

\section{RECOMMENDATIONS}

Based on this case report, any physician needs to clarify the condition of infants with congenital anomalies to their parents. Beforehand, medical professionals must sensitively detect all of the abnormalities that could be found during the first ages of infancy to facilitate the education process to patients' family. Patients with Apert syndrome cannot overcome feeding problems independently. To optimize the patients' condition before palatoplasty, the nutritional status becomes very integral to their condition. In consequence, feeding difficulties prompt developmental problems might occur. Nevertheless, supports from families and societies would be indispensable to patient care.

On the other hand, the report of Apert syndrome is still very rare worldwide which makes this dysmorphology remains enigmatic. Further investigation has to be performed to rule its pathophysiology. However, the reports and studies of such anomalies were still too limited because of the cases' rarity. Further investigation is still needed to understand more about such syndrome.

\section{REFERENCES}

[1] Verma S, Draznin M. Apert
syndrome. Dermatol Online J.
2005;11(1):405-8.


Joosten KFM, Versnel SL, van Nieuwenhoven CA, Wolvius EB, et al. Apert syndrome: the Paris and Rotterdam philosophy. Expert Opin Orphan Drugs. 2017;5(7):599-605. doi:

10.1080/21678707.2017.1335195

[3] Wenger TL, Hing A V, Evans KN. Apert Syndrome Summary Genetic counseling. 2020:1-26.

[4] Ileri Z, Goyenc YB. Apert syndrome: A case report. Eur J Dent. 2012;6(1):110-3. doi: 10.1055/s0039-1698939

[5] Das S, Munshi A. Research advances in Apert syndrome. J Oral Biol Craniofacial Res. 2018;8(3):194-9. doi: 10.1016/j.jobcr.2017.05.006

[6] Tyagi S, Kumar S, Singla $M$. Etiology, symptoms and treatment of Apert Syndrome, A congenital disorder: An overview. Int Pharma Bio Sci. 2010;1(3):1-7.

[7] Pereira V, Sacher P, Ryan M, Hayward R. Dysphagia and nutrition problems in infants with Apert syndrome. Cleft Palate-Craniofacial J. 2009;46(3):285-91. doi: 10.1597/08-010.1

[8] Chow I, Purnell CA, Hanwright PJ, Gosain AK. Evaluating the Rule of 10s in Cleft Lip Repair: Do Data Support Dogma?. Plast Reconstr Surg. 2016;138(3):670-9. doi: $\underline{10.1097 / P R S .0000000000002476}$ 